\title{
Research on the Micro-blog Strategy of the Ideological and Political Education in Colleges
}

\author{
Yun fang $\mathrm{An}^{1}$ \\ ${ }^{1}$ Department of Law, \\ Hebei Finance University, \\ Baoding,China
}

\author{
Fan $\mathrm{GaO}^{2}$ \\ ${ }^{2}$ Department of Accounting, \\ Hebei Finance University, \\ Baoding,China
}

\begin{abstract}
The rapid development of the micro-blog has a profound impact on the daily life of people. The arrival of the era of the micro blog, not only changes the traditional way of information dissemination, but also has an extremely important influence on college students and brings new challenges to the ideological and political education in colleges. The analysis of the challenges of micro blog to college students' ideological and political education, and the problem of college micro blog ideological and political education, can try to explore the strategy of college micro blog ideological and political education optimization.
\end{abstract}

Keywords: Micro-blog; College students; Ideological and political education

\section{INTRODUCTION}

The rapid development of the network provides a rare opportunity for the ideological and political education in colleges and universities, but also brings a huge challenge. The constantly updated network tools, such as QQ, BBS, and Fetion, not only make a profound impact on the ideological and political education in colleges and universities, but also bring a new topic for the ideological and political education workers. As the emerging network media, the application of micro-blog quickly attracts more and more attention. As a tool for college students in hot pursuit of the network, it has a profound impact on the college students' outlook on life, world outlook and value outlook. The Eighteenth National Congress of the CPC pointed out that we must strengthen and improve the construction of the network content, develop the main melody of the Internet; strengthen management of network society, promote the orderly operation of the network specifications. This requires that colleges and universities should adapt to the new requirements of the network era, pay more attention to the exploration and research of network ideological and political education, and better serve for the ideological and political education work ${ }^{[1]}$.

\section{The challenges of micro-blog to college students' ideological and political education}

As a product of the development of personalized Internet technology, micro-blog enriches the teaching content of the ideological and political education, improve the teaching methods and enhances teaching effect. In addition, it also brings many challenges to the ideological and political education in colleges.

(1) The information is more and more complex, and it is difficult to get the students' dynamics.

The traditional ideological and political education is often the face-to-face communication between the teachers and students, and the ideological and political workers can get the students' ideological trends more convenient and accurate. However, in the micro world, the information source has become very diverse, and the information acquired by students becomes more and more complex. The immediate information share and communication function of micro-blog make it harder to require the ideological trend of the students. The traditional idea of dynamic 
acquisition method already could not adapt to the challenges proposed by micro-blog and other new media.

(2) The main consciousness is strong, which gives a higher requirements for the ideological and political education way.

Because there are many celebrities using micro-blog, students can directly communicate with them and get the understandings. Through the sharing of educational resources among colleges and universities can enlarge students' knowledge scope and channels, which in some extent changed to college teachers as the subject of ideological and political education situation. Because micro-blog is affected by diverse ideological collisions and trendy thinking, the traditional ideological and political education interest of the students is weak. At the same time, it also uncertainty and uncontrollability to the ideological and political education in colleges. However, the traditional way of ideological and political education is mainly based on classroom teaching and daily communication, already can not adapt to the requirements of the current development, which to the methods of ideological and political education proposed higher requirements.

(3) The difficulty of the work is increasing, and the quality of the ideological and political educators is higher.

The development of the micro-blog provides a broader source of information, has a profound impact on students, and puts forward higher work requirements to the ideological and political education in colleges. Under the new media environment, it is necessary for ideological and political workers to have a good knowledge of the network, dealt with network information more quickly and flexibly, and constantly improve and perfect the way of ideological and political education by means of network, in order to achieve the continuous development of ideological and political work in colleges.

\section{The problems existed in the micro-blog ideological and political education}

(1) Thought is not seriously enough, still influenced by the traditional concept.

At present, micro-blog is widely spread among students in colleges and universities. Whether it is the college's official micro-blog and college teachers and students are keen to use micro-blog to communicate and share information, especially the students born after 1990. Research shows that 90 groups for the use of micro-blog tend to be concentrated in the entertainment category, the vast most students just in order to kill the boring time to use micro-blog. It really reflect the current college students can not use the micro-blog effectively, which need a effectively guide. At the same time, many colleges and universities ideological and political education workers are not aware of micro-blog as an effective platform for ideological and political education. Even some of the ideological and political education workers don't know what is micro-blog. Influenced by the traditional ideas and conservative ideas, as the effective platform for the ideological and political education, micro-blog has not been used effectively.

(2) The interaction is not flexible enough to build a platform effectively.

First is the information content is thin. Some colleges only use micro-blog as a platform for theory and policy releasing, such as school dynamics and academic information, whose content are relatively serious. If there is no effective way of interaction, the students will be difficult to communicate with the ideological and political educators effectively, and it is also difficult to obtain the real dynamics of the students. In practical work, ideological and political workers failed to seize the social hot spots and the focus of learning life which are shared on the micro-blog and missed the ideological and political education initiative.

(3) The operations are relatively decentralized, and there is no an effective organizational system.

Although some colleges and universities have carried out ideological and political education work effectively through the micro-blog, the operation is relatively scattered, failed to form an effective organization system, and the corresponding is lack of effective supervision. The influence of most of ideological and political workers who have opened the micro-blog is not big. And there is a difference between each others, which also makes the 
overall effect is difficult to implement. The linkage effect of each colleges is not strong, which makes the communication efficiency of the information is reduced. The effect of the information dissemination is relatively low, and the corresponding cost is relatively high ${ }^{[2]}$.

\section{The optimization strategy of the micro-blog ideological and political education in colleges}

(1) Integrate into the students, and promote communication and exchange.

Micro-blog for the current ideological and political education workers, is a better platform to carry out communication and education. At present, the ideological and political education work tends to be inflexible and old-fashioned. Therefore, colleges and universities can open the official micro-blog, and the workers of Ideological and political education can also open a personal micro-blog, and try to integrate into the students. Using the issuance of campus activities and events and sincere exchanges between students to attract students to have a better campus life and enhance the emotional connection between teachers and students.

(2) Strengthen the operation management and the construction of platform.

College micro blog has become a new channel for displaying images, transmitting information and guiding public opinion, and it is a new platform for college ideological and political education. The campus micro blog is not only conducive to the development of ideological and political education, but also conducive to the creation of the image of the college. In the process of college micro-blog operation management, we should first define the positioning and customer base, and understand the students' network communication habits. When distributing content and communicating, it is better to combine with the propagation characteristics of new media, adjust the language style, use lively and vivid language, avoid rigid document type of language, make students more willing to accept. At the same time, it is necessary to enhance interactivity and constantly improve the micro-blog operation skills. Good communication is an important way to improve the ideological education in colleges and universities.

(3) Strengthen information management and guide correct public opinion.

With the continuous development of micro-blog and other new media, the dissemination of information becomes extremely rapid, and the information identification difficulty is further increased, which bring challenges to the management of information and network public opinion in colleges. Colleges should set up special network information and public opinion processing group, give the corresponding powers and responsibilities, strengthen the network information investigation. At the same time, strengthen the personal quality of the network information administrators training, do not do harm to the interests of students and steal student privacy thing ${ }^{[3]}$.

\section{Conclusions}

As a new thing, micro-blog represents the social progress and the change of the times. The development of the micro-blog brings a new opportunity for the development of college students' ideological and political education. As educators, we should correct understanding to the micro-blog which contains tremendous strength. It is necessary for us to give full play to the advantages of "micro public opinion", vigorously carry forward the patriotism, collectivism and socialism, effectively carry out various forms of ideological and political education activities, make the ideological and political education industry and trade more close to students, close to the campus, close to the actual, and create ideological and political education work in the new situation. 


\section{References}

[1] Liu Jianzheng, "Main Relation of Mircoblog in College Students' Ideological and Political Education," Journal of Beihua University (Social Sciences), pp. 134-137, 2012.

[2] Wang Yanhong, "The Negative Effect of the Ideological and Political Education about Micro-blog and Active
Control," Journal of Jimei university, pp. 92-95, 2012.

[3] Huang Danlin, "Interactive Model of Ideological and Political Education on the Platform of Micro Blog," Journal of Anqing Teachers College (Social Science Edition), pp. 102-105, 2011. 